\title{
Metode Automatic clustering-fuzzy logical relationships pada Peramalan Jumlah Penduduk di Kota Makassar
}

\author{
Muhammad Abdy ${ }^{1}$, Rahmat Syam ${ }^{1}$, dan Elfira Haryanensi $A^{1, \text { a) }}$ \\ ${ }^{1}$ Jurusan Matematika FMIPA Universitas Negeri Makassar, 90224 \\ a)elfiraputrif105@gmail.com
}

\begin{abstract}
Abstrak. Penelitian ini merupakan penerapan metode automatic clustering-fuzzy logical relationships unruk meramalkan jumlah penduduk di Kota Makassar menggunakan data sekunder BPS Kota Makassar yang bertujuan memprediksi jumlah penduduk tahun 2017-2021. Penelitian diawali dengan penentuan panjang interval, nilai tengah panjang interval, membuat relasi logika fuzzy, fuzzifikasi, defuzzifikasi, dan menghitung nilai error hasil ramalan dengan metode Mean Absolute Percentage Error. Hasil penelitian ini menunjukkan bahwa ramalan jumlah penduduk di Kota Makassar dari tahun 2016 ke 2017 meningkat, tahun 2017 sampai tahun 2019 menurun, dan pada tahun 2019-2021 meningkat dengan keakuratan yang sangat bagus.
\end{abstract}

Kata kunci:Automatic clustering-fuzzy logical relationships, Fuzzy Time Series,TeoriFuzzy

\begin{abstract}
This research is the application of the forecasting method of fuzzy time series which is the method of automatic clustering fuzzy-logical relationships in forecasting the population of Makassar City using secondary data from BPS Makassar city which aims to predicting the population in year 2017-2021. The discussion starting from the determination of the length of the interval, determining the value of the middle length interval, making relations of fuzzy logic, fuzzification, defuzzification, and calculating the error value of the forecasting result by using the method of Mean Absolute Percentage Error. The result of this research shows that the predictions of the population of Makassar City from 2016 to 2017 increased, from 2017 to 2019 decreased, and in 2019-2021 increased with the very good accuracy.
\end{abstract}

Keywords: Automatic Clustering-Fuzzy Logical Relationships, Fuzzy Time Series,Fuzzy Theory

\section{PENDAHULUAN}

Himpunan kabur (fuzzy set) mempunyai peranan yang penting dalam perkembangan matematika khususnya dalam matematika himpunan. Ide himpunan kabur di awali dari matematika dan teori sistem dari Lotfi Asker Zadeh pada tahun 1965. Sampai saat ini banyak penelitian-penelitian yang menggunakan teori himpunan kabur, salah satunya adalah fuzzy time series.

Fuzzy time series merupakan metode peramalan menggunakan aturan-aturan fuzzy yang dapat menangkap pola dari data yang telah lalu untuk memproyeksikan data yang akan datang dan prosesnya juga tidak membutuhkan suatu sistem pembelajaran dari sistem yang rumit (Robandi, 2006). Metode fuzzy time series pertama kali diperkenalkan oleh Song \& Chissom (1993) mampu menangani masalah data samar dan tidak lengkap yang direpresentasikan sebagai nilai-nilai linguistik dalam keadaan tidak tentu. Akan tetapi, Lee, Wang, \& Chen (2007) menyatakan bahwa hasil peramalan menggunakan metode tersebut masih memiliki nilai Mean Square Error (MSE) yang relatif besar dengan tingkat keakuratan yang masih rendah sehingga terus dikembangkan. Oleh karena itu, Chen, Wang, \& Pan(2009) memperkenalkan metode modifikasi fuzzy time series 
untuk meramalkan data penerimaan mahasiswa Universitas Alabamayang dikenal dengan Automatic clustering Tecnique and Fuzzy logical relationships (ACFLR).

Beberapa penelitian sebelumnya menyimpulkan bahwa metode ACFLR menghasilkan nilai MSE yang paling minimum diantara metode Song and Chissom's, metode Sullivian and Woodall's, metode Chen's, dan metode Huang's pada penyelesaian kasus yang sama (Endaryati \& Kurniawan, 2015). Begitupula pada peneliti lain yang juga membandingkan metode tersebut dengan metode lain, seperti Kurniawan (2014) antara metode Automatic Clusteringand Fuzzy Logical Relationships dengan ARIMA dan Endaryati \& Kurniawan (2015) antara metode Automatic Clustering and Fuzzy Logical Relationshipsdengan Single Exponential Smoothing, keduanya menyimpulkan bahwa metode tersebut memiliki tingkat keakuratan yang lebih tinggi ditunjukkan dengan nilai error yang diperoleh lebih minimum.Salah satu masalah yang menarik untuk diramalkan menggunakan metode peramalan ACFLR adalah jumlah penduduk.

Jumlah penduduk adalah salah satu masalah yang dihadapi oleh Negara Indonesia saat ini, dengan jumlah penduduk yang mencapai 257.912.349 jiwa. telah membawa Indonesia menduduki posisi ke-4 di dunia berdasarkan jumlah penduduk terbesar di dunia. Seiring dengan jumlah penduduk yang besar, kepadatan penduduk juga terus meningkat dari tahun ke tahun dan menyebabkan permasalahan seperti kemiskinan, pengangguran, serta kualitas sumber daya manusia yang masih rendah. Salah satu kota besar di Indonesia dengan jumlah penduduk yang besar pula adalah kota Makassar. Berdasarkan hasil sensus, jumlah penduduk di kota Makassar dari tahun 2002-2016 terus meningkat secara signifikan dengan jumlah penduduk mencapai 1,469,601 jiwa dengan laju pertumbuhan penduduk rata-rata sebesar 1,65 persen per tahunnya (BPS, 2016). Untuk mengontrol jumlah penduduk di masa yang akan datang dapat dilakukan dengan melakukan peramalan yang bertujuan untuk memprediksi jumlah penduduk kedepannya.

Oleh karena itu, pada artikel ini dibahas mengenai metode Automatic Clustering-Fuzzy Logical Relationships pada peramalan jumlah penduduk di kota makassar dan akan dihitung nilai error hasil peramalannya menggunakan metode Mean Absolute Percentage Error.

\section{Himpunan Fuzzy}

Misalkan $U$ adalah suatu himpunan semesta dengan $x \in U$. Suatu himpuan kabur $\tilde{A}$ dalam $U$ adalah himpunan pasangan-pasangan terurut elemen $x$ dengan derajat keanggotannya seperti pada persamaan (1).

$$
\tilde{A}=\left\{\left(x, \mu_{\tilde{A}}(x) \mid x \in U\right)\right\}
$$

$\mu_{\tilde{A}}$ merupakan fungsi keanggotaan yang memetakan setiap $x \in U$ ke interval $[0,1]$. Nilai dari $\mu_{\tilde{A}}(x)$ dalam interval $[0,1]$ disebut nilai keanggotaan atau derajat keanggotaan dari elemen $x$ dalam $\tilde{A}$, sedangkan interval $[0,1]$ sendiri disebut ruang keanggotaan.

Anggota dari ruang keanggotaan himpunan biasa hanyalah nol atau satu, sehingga himpunan kabur merupakan perluasan dari himpunan biasa. Derajat keanggotaan menunjukkan besarnya keterlibatan suatu anggota dalam suatu himpunan (Abdy, 2008).

\section{Fuzzy Time Series}

Fuzzy time series (FTS) yang pertama kali dikembangkan oleh Song dan Chissom pada tahun 1993 adalah metode peramalan data yang menggunakan prinsip fuzzy sebagai dasarnya. Sistem peramalan dengan FTS menangkap pola data yang telah lalu kemudian digunakan untuk memproyeksikan data yang akan datang (Kurniawan, 2014).

Konsep dasar FTS yang diperkenalkan oleh Song dan Chissom (1993) yang nilai FTS direpresentasikan dengan himpunan fuzzy seperti berikut: 
Definisi 1

Didefinisikan $U$ adalah semesta pembicaraan dengan $U=\left\{u_{1}, u_{2}, u_{3}, \ldots, u_{n}\right\}$. Sebuah himpunan fuzzy $\tilde{A}$ dalam semesta pembicaraan $U$ dapat direpresentasikan seperti pada persamaan (2).

$$
\widetilde{\mathrm{A}}=f_{A}\left(u_{1}\right) / u_{1}+f_{A}\left(u_{2}\right) / u_{2}+\cdots+f_{A}\left(u_{n}\right) / u_{n}
$$

dengan $f_{A}$ adalah fungsi keanggotaan dari himpunan fuzzy $\mathrm{A}, f_{A}: \mathrm{U} \rightarrow[0,1], f_{A}\left(u_{i}\right)$ merupakan tingkat keanggotaan dari $u_{i}$ dalam himpunan fuzzy $\mathrm{A}$, dan $1 \leq i \leq n$.

Definisi 2

Misalkan $Y(t)(t=\cdots, 0,1,2, \ldots)$, sebuah himpunan bagian dari $R$, yang menjadi himpunan semesta dengan himpunan fuzzy $f_{i}(t)(t=1,2, \ldots)$ telah didefinisikan sebelumnya dan dijadikan $F(t)$ menjadi kumpulan dari $f_{i}(t)(t=\cdots, 0,1,2, \ldots)$, maka $F_{(t)}$ dinyatakan sebagai fuzzy time series terhadap $Y(t)(t=\cdots, 0,1,2, \ldots)$.

\section{Definisi 3}

Jika ada sebuah fuzzy logical relationships $R(t, t-1)$ sedemikiansehingga $F(t)=F(t-$ 1) ${ }^{\circ} R(t, t-1)$, dengan $F(t)$ dan $F(t-1)$ merupakan himpunan fuzzy dan ${ }^{\circ}$ merupakan operator komposisi maks-min, maka $F(t)$ disebut diperoleh dari $F(t-1)$, dilambangkan oleh fuzzy logical relationshipssebagai $F(t-1) \rightarrow f(t)$. Jika $F(t-1)=A_{i}$ dan $F(t)=A_{j}$, dengan $A_{i}$ dan $A_{j}$ adalah himpunan fuzzy, maka fuzzy logical relationships antara $F(t-1)$ dan $F(t)$ dapat ditunjukkan oleh $A_{i} \rightarrow A_{j}$, dengan $A_{i}$ disebut current state dan $A_{j}$ disebut next state.

\section{Metode Automatic Clustering-Fuzzy Logical Relationships}

Sebelum dilakukan peramalan, langkah pertama adalah menentukan interval dengan menggunakan algoritma clustering. Interval yang dimaksud adalah jarak untuk masing-masing cluster. Untuk menghitungnya digunakan hasil modifikasi algoritma clustering yang dilakukan oleh Chen, dkk, (2009) dengan langkah-langkah sebagai berikut:

1. Urutkan data dari yang terkecil sampai yang terbesar.Asumsikan bahwa dalam data tersebut tidak ada yang nilainyasama.

2. Letakkan datum numerik pertama (datum terkecil dalam urutan data) pada cluster yang sudah ada.

3. Berdasarkan clustering pada tahap 2, sesuaikan isi dari cluster tersebut.

4. Transformasi cluster-cluster tersebut dalam interval yang berdekatan.

5. Untuk setiap interval yang didapatkan pada tahap 4 , bagi setiap interval tersebut dalam $p$ sub interval dimana $p \geq 1$.

Setelah didapatkan interval dengan menggunakan automatic clustering technique, selanjutnya dapat dihitung nilai ramalannya dengan langkah-langkah sebagai berikut Chen, dkk, (2009):

1. Menentukan himpunan semesta dan menerapkan algoritma automatic clusteringuntuk membuat interval-interval lalu menghitung titik tengah setiap interval.

2. Melakukan proses fuzzifikasi.

3. Membuat fuzzy logical relationships dan fuzzy logical relationships groups.

4. Melakukan proses defuzzifikasi. 


\section{METODE PENELITIAN}

Penelitian yang dilakukan merupakan penelitian terapan dengan studi kasus peramalan jumlah penduduk di Kota Makassar tahun 2017-2021menggunakan metode Automatic clustering-fuzzy logical relationships, data yang digunakan adalah data jumlah penduduk di Kota Makassar tahun 1998-2017 (tanpa memperhatikan pengaruh dan fenomena pada data). Metode yang digunakan pada penelitian ini memiliki 2 tahap, yaitu mencari panjang interval menggunakan algoritma automatic clustering, selanjutnya mencari hubungan relasi logika fuzzy untuk medapatakan hasil peramalan.

\section{HASIL PENELITIAN}

\section{Kajian matematis metode Automatic clustering-fuzzy logical relationships}

Algoritma automatic clusteringoleh Chen, dkk, (2009) disajikan sebagai berikut:

\section{Langkah 1a:}

Data yang terdiri atas $n$ data numerik berbeda diurutkan dalam urutan data menaik. Diasumsikan bahwa urutan data menaik tanpa data ganda ditunjukkan sebagai berikut :

$$
d_{1}, d_{2}, d_{3}, \ldots, d_{i}, \ldots d_{n} .
$$

Berdasarkan barisan di atas dihitung nilai dari “average_diff" sebagaimana persamaan (3).

$$
\text { average_diff }=\frac{\sum_{i=1}^{n-1}\left(d_{i+1}-d_{i}\right)}{n-1}
$$

dengan "average_diff" menunjukkan rata-rata perbedaan antara setiap data yang berdekatan dalam urutan menaik.

\section{Langkah 2a:}

Data numerik pertama dalam urutan data menaik ditetapkan sebagai cluster saat ini. Berdasarkan nilai average_diff ditentukan apakah data numerik berikutnya dalam urutan data menaik dapat dimasukkan ke dalam cluster saat ini atau perlu dimasukkan ke dalam cluster baru didasarakan pada prinsip berikut:

Prinsip 1: Diasumsikan bahwa cluster saat ini adalah cluster pertama dan di dalamnya hanya ada satu data numerik $d_{1}$ dan diasumsikan bahwa $d_{2}$ adalah data numerik terdekat dari $d_{1}$, ditampilkan sebagaimana berikut :

$$
\left\{d_{1}\right\}, d_{2}, d_{3}, \ldots, d_{n} .
$$

Jika $d_{2}-d_{1} \leq$ average_diff, maka $d_{2}$ diletakkan ke dalam cluster saat ini yang memuat $d_{1}$. Jika tidak, dibentuk cluster baru untuk $d_{2}$ dan ditetapkan cluster baru yang memuat $d_{2}$ menjadi cluster saat ini

Prinsip 2: Diasumsikan cluster saat inibukan cluster pertama dan ada lebih dari satu data numerik pada cluster saat ini. Diasumsikan bahwa $d_{1}$ adalah data numerik terbesar pada cluster saat inidan diasumsikan bahwa $d_{j}$ adalah data numerik terdekatdari yang ditampilkan sebagaimana berikut : 


$$
\left\{d_{1}, \ldots\right\}, \ldots,\{\ldots\},\left\{\ldots, d_{i}\right\}, d_{j}, \ldots, d_{n} .
$$

Jika $d_{j}-d_{i} \leq$ average diff dan $d_{j}-d_{i} \leq$ cluster diff, maka $d_{j}$ diletakkan ke dalam cluster saat ini yang memuat $d_{i}$. Jika tidak, dibentuk cluster baru untuk $d_{j}$ dan ditetapkan cluster baru yang memuat $d_{j}$ menjadi cluster saat ini, dengan “cluster_diff' menunjukkan perbedaan dalam cluster yang dihitung sebagaimana persamaan (4).

$$
\text { cluster_diff }=\frac{\sum_{i=1}^{n-1}\left(c_{i+1}-c_{i}\right)}{n-1}
$$

dengan $c_{1}, c_{2}, \ldots, c_{n}$ menunjukkan data di dalam cluster saat ini.

Prinsip 3: Diasumsikan cluster saat ini bukan cluster pertama dan hanya ada satu data numerik $d_{j}$ pada cluster saat ini. Diasumsikan $d_{k}$ adalah data numerik terekat dari $d_{j}$ dan diasumsikan $d_{i}$ adalah data numerik terbesar dalamcluster yang merupakan cluster terdahuludari cluster saat ini, ditampilkan sebagai berikut :

$$
\left\{d_{1}, \ldots\right\}, \ldots,\{\ldots\},\left\{\ldots, d_{i}\right\},\left\{d_{j}\right\} d_{k}, \ldots, d_{n}
$$

Jika $d_{k}-d_{j}$ saverage diff dan $d_{k}-d_{j} \leq d_{j}-d_{i}$, maka $d_{k}$ diletakkan ke dalam cluster saat ini yang memuat $d_{j}$. Jika tidak, dibentuk cluster baru untuk $d_{k}$ dan ditetapkan cluster baru yang memuat $d_{k}$ menjadi cluster saat ini.

\section{Langkah 3a:}

Berdasarkan clustering yang diperoleh pada langkah 2, sesuaikan isi dari cluster tersebut berdasarkan prinsip berikut:

Prinsip 1: Jika sebuah cluster memiliki lebih dari dua data, maka data numerik terkecil dan data numerik terbesar dipertahankan lalu data yang lain dihapus.

Prinsip 2: Jika sebuah cluster hanya memiliki dua data, maka dua data tersebut dipertahankan .

Prinsip 3: Jika sebuah cluster hanya memiliki satu data numerik $d_{q}$, maka nilai dari " $d_{q}-$ average_diff' dan" $d_{q}+$ average_diff" diletakkan ke dalam cluster dan $d_{q}$ dihapus dari cluster. Jika situasi berikut terjadi, cluster perlu disesuaikan lagi :

Situasi 1: Jika sesuatu terjadi di cluster pertama, maka hapus nilai dari “ $d_{q}$ - average_diff” dan ditetapkan $d_{q}$ sebagai penggantinya.

Situasi 2: Jika situasi terjadi di cluster terakhir, maka hapus nilai dari " $d_{q}+$ average_diff" dan ditetapkan $d_{q}$ sebagai penggantinya.

Situiasi 3: Jika nilai dari “ $d_{q}$-average_diff” lebih kecil pada nilai terkecil dalam cluster yang terdahulu, maka semua tindakan dalam Prinsip 3 dibatalkan.

\section{Langkah 4a:}

Diasumsikan bahwa hasil clustering yang diperoleh dari langkah 3a ditampilkan sebagai berikut :

$$
\left\{d_{1}, d_{2}\right\},\left\{d_{3}, d_{4}\right\},\left\{d_{5}, d_{6}\right\}, \ldots,\left\{d_{r}\right\},\left\{d_{s}, d_{t}\right\}, \ldots,\left\{d_{n-1}, d_{n}\right\}
$$

Cluster-cluster diubah kedalam interval dengan sub-langkah berikut : 
Langkah 4.1: Cluster pertama $\left\{d_{1}, d_{2}\right\}$ diubah ke dalam interval $\left[d_{1}, d_{2}\right\}$.

Langkah 4.2: Jika interval saat ini $\left[d_{i}, d_{j}\right\}$ dan cluster saat ini $\left\{d_{k}, d_{i}\right\}$, maka

(1) Jika $d_{j} \geq d_{k}$, maka dibentuk sebuah interval $\left[d_{j}, d_{1}\right)$ yang ditetapkan menjadi interval saat ini dan cluster selanjutnya $\left\{d_{m}, d_{n}\right\}$, ditetapkan menjadi cluster saat ini.

(2) Jika $d_{j}<d_{k}$, maka $\left\{d_{k}, d_{l}\right\}$ diubah ke dalam interval $\left[d_{k}, d_{l}\right)$ dan dibentuk sebuah interval baru $\left[d_{j}, d_{k}\right)$ di antara $\left[d_{i}, d_{j}\right)$ dan $\left[d_{k}, d_{l}\right)$. $\left[d_{k}, d_{l}\right)$ ditetapkan menjadi interval saat ini dan cluster selanjutnya $\left\{d_{m}, d_{n}\right\}$ ditetapkan menjadi cluster saat ini. Jika interval saat ini $\left[d_{i}, d_{j}\right)$ dan cluster saat ini adalah $\left\{d_{k}\right\}$, maka interval saat ini $\left[d_{i}, d_{j}\right)$ diubah ke dalam $\left[d_{i}, d_{k}\right)$ yang ditetapkan menjadi interval saat ini dan cluster selanjutnya ditetapkan menjadi cluster saat ini.

(3) Interval terakhir merupakan interval selang tutup $\left[d_{m}, d_{n]}\right.$.

Langkah 4.3: Interval saat ini dan cluster saat ini diperiksa berulang kali sampai semua cluster telah berubah menjadi menjadi interval-interval.

\section{Langkah 5a:}

Untuk setiap interval yang diperoleh pada langkah 4a, bagi masing-masing intervalke dalam $p$ sub-interval, dengan $p \geq 1$.

Algoritma Automatic clustering-fuzzy logical relationshipsdisajikan oleh Chen, dkk. (2009) yaitu sebagai berikut:

Langkah 1b: Himpunan semesta

Himpunan semesta $U=\left[D_{\min }, D_{\max }\right]$ ditentukan sesuai data historis yang ada. Algoritma automatic clustering diterapkan untuk membuat interval-interval dari data historis. Kemudian setiap interval yang terbentuk dihitung titik tengahnya.

Langkah 2b: Proses fuzzifikasi

Diasumsikan ada $n$ interval yang didapatkan dari langkah pertama yaitu $u_{1}, u_{2}, \ldots, u_{n}$, kemudiann didefiniskan setiap himpunan fuzzy $_{i}$, dengan $1 \leq i \leq n$ sebagaimana persamaan (5).

$$
\begin{aligned}
& A_{1}=1 / u_{1}+0,5 / u_{2}+0 / u_{3}+0 / u_{4} \ldots+0 / u_{n-1}+0 / u_{n} \\
& A_{2}=0,5 / u_{1}+1 / u_{2}+0,5 / u_{3}+0 / u_{4} \ldots+0 / u_{n-1}+0 / u_{n} \\
& A_{3}=0 / u_{1}+0,5 / u_{2}+1 / u_{3}+0 / u_{4} \ldots+0 / u_{n-1}+0 / u_{n} \\
& A_{n}=0 / u_{1}+0 / u_{2}+0 / u_{3}+0 / u_{4} \ldots+0,5 / u_{n-1}+1 / u_{n}
\end{aligned}
$$

Fuzzifikasi setiap data numerik kedalam himpunan fuzzy. Jika data numerik masuk dalam interval $u_{1}$, dengan $1 \leq i \leq n$, maka data numerik di fuzzifikasi ke dalam himpunan fuzzy $A_{i}$. Himpunan fuzzy $A_{1}, A_{2}, A_{3}, \ldots, A_{n}$ merupakan suatu himpunan-himpunan fuzzy yang variabel linguistiknya ditentukan sesuai dengan keadaan semesta. Himpunan fuzzy $A_{i}$ merupakan himpunan fuzzy jumlah penduduk paling sedikit sedangkan himpunan fuzzy $A_{n}$ merupakan himpunan fuzzy jumlah penduduk paling banyak.

Langkah 3b: fuzzy logical relationships 
Membuat fuzzy logical relationships berdasarkan pada fuzzifikasi yang diperoleh pada langkah 2. Jika hasil fuzzifikasi tahun $t$ dan $t+1$ adalah $A_{i}$ dan $A_{k}$ maka terbentuk fuzzy logical relationships" $A_{i} \rightarrow A_{k}$ ", dengan $A_{i}$ dan $A_{k}$ berturut-turut disebut current state dan next state dari fuzzy logical relationships. Berdasarkan current state dari fuzzy logical relationships, dibuat fuzzy logical relationships groups, yaitu fuzzy logical relationships yang dimiliki current state sama dimasukkan ke dalam fuzzy logical relationships yang sama.

Langkah 4b: Proses defuzzifikasi

Proses defuzzifikasi mengubah suatu besaran fuzzy menjadi besaran tegas. Keluaran dalam proses ini yaitu suatu nilai peramalan yang ditentukan dengan menggunakan prinsip-prinsip berikut:

1. Jika hasil fuzzifikasi pada tahun tadalah $A_{j}$ dan hanya ada satu fuzzy logical relationshipsdi dalam fuzzy logical relationships group yang memiliki current state $A_{j}$ ditunjukkan sebagai berikut: $\rightarrow A_{k}$, maka peramalan pada tahun $t+1$ adalah $m_{k}$, dengan $m_{k}$ adalah titik tengah dari interval $u_{k}$ dan nilai keanggotaan maksimum dari himpunan fuzzy $A_{k}$ terjadi pada interval $u_{k}$.

2. Jika hasil fuzzifikasipada tahun $t$ adalah $A_{j}$ dan ada fuzzy logical relationships berikut di dalam grup fuzzy logical relationship yang memiliki current state $A_{j}$, ditunjukkan sebagaimana persamaan (6).

$$
A_{j} \rightarrow A k_{1}\left(x_{1}\right), A k_{2}\left(x_{2}\right), \ldots A k_{p}\left(x_{p}\right)
$$

maka peramalan pada tahun $t+1$ dihitung sebagaimana persamaan (7).

$$
\frac{x_{1} \times m k_{1}+x_{2} \times m k_{2}+\cdots+x_{p} \times m k_{p}}{x_{1}+x_{2}+\cdots+x_{p}}
$$

dengan $x_{i}$ menunjukkan jumlah dari fuzzy logical relationships " $A_{j} \rightarrow A_{k i}$ " di dalam fuzzy logical relationship group, $1 \leq i \leq p, m_{k 1}, m_{k 2}, \ldots$, dan $m_{k p}$ berturut-turut adalah titik tengah dari interval $u_{k 1}, u_{k 2}, \ldots$, dan $u_{k p}$, dan nilai keanggotaan maksimum dari himpunan fuzzy $A_{k 1}, A_{k 2}, \ldots$, dan $A_{k p}$ berturut-turut terjadi pada interval $u_{k 1}, u_{k 2}, \ldots$, dan $u_{k p}$.

3. Jika hasil fuzzifikasi pada tahun $\mathrm{t}$ adalah $A_{j}$ dan ada fuzzy logical relationshipsdi dalam fuzzy logical relationship group yang memiliki current state $A_{j}$ ditunjukkan sebagaimana persamaan (8).

$$
A_{j} \rightarrow \#
$$

dengan simbol " \#" menunjukkan sebuah nilai yang tidak diketahui, maka peramalan pada tahun $t+1$ adalah $m_{n}$, dengan $m_{n}$ adalah titik tengah dari interval $u_{n}$ (interval terakhir).

Peramalan jumlah penduduk di Kota Makassar menggunakan metode Automatic clustering-fuzzy logical relationships 
TABEL 1.Data jumlah penduduk di kota Makassar tahun 1998-2016

\begin{tabular}{ccc}
\hline No & Tahun & Data Jumlah Penduduk \\
\hline 1 & 1998 & $1,168,515$ \\
2 & 1999 & $1,191,456$ \\
3 & 2000 & $1,112,688$ \\
4 & 2001 & $1,130,384$ \\
5 & 2002 & $1,127,785$ \\
6 & 2003 & $1,160,011$ \\
7 & 2004 & $1,179,023$ \\
8 & 2005 & $1,193,434$ \\
9 & 2006 & $1,223,540$ \\
10 & 2007 & $1,235,239$ \\
11 & 2008 & $1,253,656$ \\
12 & 2009 & $1,273,349$ \\
13 & 2010 & $1,339,374$ \\
14 & 2011 & $1,352,136$ \\
15 & 2012 & $1,364,606$ \\
16 & 2013 & $1,408,072$ \\
17 & 2014 & $1,429,242$ \\
18 & 2015 & $1,449,401$ \\
19 & 2016 & $1,469,601$ \\
\hline
\end{tabular}

Setalah menerapkan algoritma automatic clustering, maka terbentuk interval sebagai berikut:

$$
\begin{array}{ll}
u_{1}=[1,112,688,1,130,384) & u_{9}=[1,273,485,1,293,178) \\
u_{2}=[1,130,384,1,160,011) & u_{10}=[1,293,178,1,339,374) \\
u_{3}=[1,160,011,1,179,023) & u_{11}=[1,339,374,1,352,136) \\
u_{4}=[1,179,023,1,191,456) & u_{12}=[1,352,136,1,389,435) \\
u_{5}=[1,191,456,1,193,434) & u_{13}=[1,389,435,1,427,901) \\
u_{6}=[1,193,434,1,223,540) & u_{14}=[1,427,901,1,449,071) \\
u_{7}=[1,223,540,1,235,239) & u_{15}=[1,449,071,1,469,230) \\
u_{8}=[1,235,239,1,273,485) & u_{16}=\{1,469,230,1,489,430)
\end{array}
$$

Membagi masing-masing interval ke dalam $\mathrm{p}$ sub-interval, di mana $p \geq 1$. Jika diambil $p=5$ maka interval yang didapat sejumlah 256 interval.

TABEL 2. Hasil fuzzifikasi jumlah penduduk dengan metode automatic clustering-fuzzy logical relationships

\begin{tabular}{cccccccc}
\hline \multirow{2}{*}{ No } & Tahun & $\begin{array}{c}\text { Jumlah } \\
\text { Penduduk }\end{array}$ & Fuzzifikasi & No & Tahun & $\begin{array}{c}\text { Jumlah } \\
\text { Penduduk }\end{array}$ & Fuzzifikasi \\
\hline 1 & 1998 & $1,168,515$ & $A_{40}$ & 11 & 2008 & $1,253,656$ & $A_{120}$ \\
2 & 1999 & $1,191,456$ & $A_{65}$ & 12 & 2009 & $1,273,349$ & $A_{128}$ \\
3 & 2000 & $1,112,688$ & $A_{1}$ & 13 & 2010 & $1,339,374$ & $A_{161}$ \\
4 & 2001 & $1,130,384$ & $A_{17}$ & 14 & 2011 & $1,352,136$ & $A_{177}$ \\
5 & 2002 & $1,127,785$ & $A_{14}$ & 15 & 2012 & $1,364,606$ & $A_{184}$ \\
6 & 2003 & $1,160,011$ & $A_{33}$ & 16 & 2013 & $1,408,072$ & $A_{200}$ \\
7 & 2004 & $1,179,023$ & $A_{49}$ & 17 & 2014 & $1,429,242$ & $A_{210}$ \\
8 & 2005 & $1,193,434$ & $A_{81}$ & 18 & 2015 & $1,449,401$ & $A_{225}$ \\
9 & 2006 & $1,223,540$ & $A_{97}$ & 19 & 2016 & $1,469,601$ & $A_{241}$ \\
10 & 2007 & $1,235,239$ & $A_{113}$ & & & & \\
\hline
\end{tabular}


Dari Tabel 2 dilihat bahwa jumlah penduduk pada tahun 1998 adalah 1,168,515 yang berada pada interval $\mathrm{u}_{40}=[1,168,329,1,169,517]$ maka jumlah penduduk pada tahun 1998 difuzzifikasi ke dalam $\mathrm{A}_{10}$. Berdasarkan tabel dapat ditentukan fuzzy logical relationships. Misalnya, karena fuzzifikasi data jumlah penduduk pata tahun 1998 adalah $\mathrm{A}_{40}$ dan fuzzifikasi data jumlah penduduk pada tahun 1999 adalah $\mathrm{A}_{65}$, maka fuzzy logical relationships antara tahun 1998 dan 1999 adalah $A_{40} \rightarrow A_{65}$, dengan $\mathrm{A}_{40}$ disebut keadaan sekarang dari fuzzy logical relationshipsdan A 65 disebut keadaan mendatang pada fuzzy logical relationships, seperti pada Tabel 3.

TABEL 3. Fuzzy logical relationships jumlah penduduk di Kota Makassar

\begin{tabular}{cc}
\hline \multicolumn{2}{c}{ fuzzy logical relationships } \\
\hline$A_{40} \rightarrow A_{65}$ & $A_{120} \rightarrow A_{128}$ \\
$A_{65} \rightarrow A_{1}$ & $A_{128} \rightarrow A_{161}$ \\
$A_{1} \rightarrow A_{17}$ & $A_{161} \rightarrow A_{177}$ \\
$A_{17} \rightarrow A_{14}$ & $A_{177} \rightarrow A_{184}$ \\
$A_{14} \rightarrow A_{33}$ & $A_{184} \rightarrow A_{200}$ \\
$A_{33} \rightarrow A_{49}$ & $A_{200} \rightarrow A_{210}$ \\
$A_{49} \rightarrow A_{81}$ & $A_{210} \rightarrow A_{225}$ \\
$A_{81} \rightarrow A_{97}$ & $A_{225} \rightarrow A_{241}$ \\
$A_{97} \rightarrow A_{113}$ & $A_{241} \rightarrow \#$ \\
$A_{113} \rightarrow A_{120}$ & \\
\hline
\end{tabular}

Berdasarkan pada keadaan saat ini pada fuzzy logical relationships, fuzzy logical relationshipsdibagi kedalam fuzzy logical relationships group, dimana fuzzy logical relationships yang memiliki kadaan saat ini yang sama dimasukkan kedalam fuzzy logical relationships group yang sama. Sehingga diperoleh hasil pengelompokan fuzzy logical relationshipsseperti pada Tabel 4.

TABEL 4. Fuzzy logical relationships groupsjumlah penduduk di Kota Makassar fuzzy logical relationships groups

\begin{tabular}{rlr}
\hline Group 1: & $A_{1} \rightarrow A_{17}$ & Group 11: $A_{120} \rightarrow A_{128}$ \\
Group 2: & $A_{14} \rightarrow A_{33}$ & Group 12: $A_{128} \rightarrow A_{161}$ \\
Group 3: & $A_{17} \rightarrow A_{14}$ & Group 13: $A_{161} \rightarrow A_{177}$ \\
Group 4: & $A_{33} \rightarrow A_{49}$ & Group 14: $A_{177} \rightarrow A_{184}$ \\
Group 5: & $A_{40} \rightarrow A_{65}$ & Group 15: $A_{184} \rightarrow A_{200}$ \\
Group 6: & $A_{49} \rightarrow A_{81}$ & Group 16: $A_{200} \rightarrow A_{210}$ \\
Group 7 : & $A_{65} \rightarrow A_{1}$ & Group 17: $A_{210} \rightarrow A_{225}$ \\
Group 8: & $A_{81} \rightarrow A_{97}$ & Group 18: $A_{225} \rightarrow A_{241}$ \\
Group 9: & $A_{97} \rightarrow A_{113}$ & Group 19: $A_{241} \rightarrow \#$ \\
Group 10: & $A_{113} \rightarrow A_{120}$ & \\
\hline
\end{tabular}

Menghitung peramalan jumlah penduduk dengan prinsip defuzzifikasi, sehingga jika akan meramalkan jumlah penduduk pada tahun 1999, maka berdasarkan Tabel 4, dapat dilihat hasil fuzzifikasi jumlah penduduk pada tahun 1998 adalah $\mathrm{A}_{40}$ dan terdapat pada group 5 fuzzy logical relatioships yaitu $A_{40} \rightarrow A_{65}$. Oleh karena itu hasil peramalan jumlah penduduk pada tahun 1999 adalah nilai tengah dari interval $\mathrm{u}_{65}$ yaitu $\mathrm{m}_{65} 1,191,518$. Berdasarkan 3 prinsip defuzzisikasi maka peramalan jumlah penduduk yang lainnya dapat ditemukan seperti pada Tabel 5. 
TABEL 5. Hasil peramalan jumlah penduduk Kota Makassar

\begin{tabular}{ccc}
\hline Tahun & Data jumlah penduduk & Hasil ramalan \\
\hline 1998 & $1,168,515$ & - \\
1999 & $1,191,456$ & $1,191,518$ \\
2000 & $1,112,688$ & $1,113,241$ \\
2001 & $1,130,384$ & $1,131,310$ \\
2002 & $1,127,785$ & $1,127,619$ \\
2003 & $1,160,011$ & 1,160606 \\
2004 & $1,179,023$ & $1,179,412$ \\
2005 & $1,193,434$ & $1,194,375$ \\
2006 & $1,223,540$ & $1,223,906$ \\
2007 & $1,235,239$ & $1,236,435$ \\
2008 & $1,253,656$ & $1,253,167$ \\
2009 & $1,273,349$ & $1,272,290$ \\
2010 & $1,339,374$ & $1,339,773$ \\
2011 & $1,352,136$ & $1,353,302$ \\
2012 & $1,364,606$ & $1,369,621$ \\
2013 & $1,408,072$ & $1,407,466$ \\
2014 & $1,429,242$ & $1,429,887$ \\
2015 & $1,449,401$ & $1,449,702$ \\
2016 & $1,469,601$ & $1,488,793$ \\
\hline
\end{tabular}

Berdasarkan metode Automatic clustering-Fuzzy logical relationships diperoleh nilai peramalan jumlah penduduk di Kota Makassar pada tahun 2017 sebanyak 1,488,793 jiwa.

Peramalan tahun selanjutnya dilakukan dengan langkah yang sama seperti sebelumnya, untuk peramalan tahun 2018 nilai hasil peramalan tahun 2017 dimasukkan kedalam data historis dan untuk peramalan tahun 2019 nilai hasil peramalan tahun 2017 dan 2018 dimasukkan kedalam data historis dan begitupun untuk tahun 2020 dan 2021.

Berdasarkan metode Automatic clustering-Fuzzy logical relationships diperoleh peramalan jumlah penduduk tahun 2018, 2019, 2020, 2021 berturut-turut adalah 1,488,194, 1,488,044, $1,506,129,1,523,472$.

\section{Keakuratan hasil peramalan menggunakan metode Automatic clustering-fuzzy logical relationships}

Mape adalah salah satu metode yang digunakan untuk mengevaluasi hasil peramalan, metode ini adalah cara yang paling akurat untuk menghitung error karena menyatakan presentase kesalahan hasil ramalan terhadap keadaan actual selama periode tertentu yng memberikan informasi presentase terlalu tinggi atau terlalu rendah. Metode ini melakukan perhitungan perbedaan antara data asli dan data hasil peramalan. Perbedaan tersebut diabsolutkan, kemudian dihitung kedalam bentuk persentase terhadap data asli. Hasil persentase tersebut kemudian didapatkan nilai meannya. Suatu model mempunyai kinerja sangat bagus jika nilai MAPE berada dibawah $10 \%$, dan mempunyai kinerja bagus jika nilai MAPE berada diantara 10\% dan 20\% (Raharja, Anggraeni, \& Aulia, 2010).

Cara menghitung MAPE menurut Makridakis (1999) sebagaimana persamaan (9) dan (10).

$$
M A P E=\frac{1}{n} \sum_{t=1}^{n}\left|P E_{t}\right|
$$

Dengan 


$$
P E_{t}=\left(\frac{Y_{t}-F_{t}}{Y_{t}}\right) \times 100
$$

Adapun nilai error yang diperoleh dari hasil peramalan jumlah penduduk seperti pada Tabel 6 .

TABEL 6. Nilai error hasil peramalan jumlah penduduk kota Makassar tahun 2017-2021 menggunakan MAPE

\begin{tabular}{cccc}
\hline Tahun & $\begin{array}{c}\text { Jumlah } \\
\text { penduduk }\end{array}$ & Prediksi & Error \\
\hline 1998 & $1,112,688$ & $1,113,241$ & 0,03 \\
1999 & $1,127,785$ & $1,127,619$ & 0,01 \\
2000 & $1,130,384$ & $1,131,310$ & 0,05 \\
2001 & $1,160,011$ & $1,160,606$ & 0,08 \\
2002 & $1,168,515$ & $1,168,923$ & 0,01 \\
2003 & $1,179,023$ & $1,179,412$ & 0,05 \\
2004 & $1,191,456$ & $1,191,518$ & 0,03 \\
2005 & $1,193,434$ & $1,194,375$ & 0,08 \\
2006 & $1,223,540$ & $1,223,906$ & 0,03 \\
2007 & $1,235,239$ & $1,233,256$ & 0,16 \\
2008 & $1,253,656$ & $1,254,774$ & 0,09 \\
2009 & $1,273,349$ & $1,273,387$ & 0,00 \\
2010 & $1,339,374$ & $1,339,773$ & 0,03 \\
2011 & $1,352,136$ & $1,353,241$ & 0,08 \\
2012 & $1,369,606$ & $1,368,709$ & 0,07 \\
2013 & $1,408,072$ & $1,409,192$ & 0,08 \\
2014 & $1,429,242$ & $1,429,265$ & 0,00 \\
2015 & $1,449,401$ & $1,449,016$ & 0,03 \\
2016 & $1,469,601$ & $1,469,179$ & 0,03 \\
2017 & $1,488,793$ & $1,488,772$ & 0,00 \\
2018 & $1,488,194$ & $1,488,772$ & 0,04 \\
2019 & $1,488,494$ & $1,488,772$ & 0,02 \\
2020 & $1,505,555$ & $1,506,100$ & 0,04 \\
2021 & $1,522,930$ & $1,523,472$ & 0,04 \\
Nilai error & & & $0,48 \%$ \\
\hline & & &
\end{tabular}

\section{PEMBAHASAN}

Penelitian ini menerapkan metode Automatic Clustering-Fuzzy Logical Relatiosnhips untuk meramalkan jumlah penduduk di Kota Makassar tahun 2017-2021, data yang digunakan adalah data jumlah penduduk tahun 1998-2016. Sebelum menerapkan metode ini, peneliti melakukan uji coba dengan meramalkan jumlah penduduk tahun 2015 dan 2016 menggunakan data jumlah penduduk tahun 1998-2014, dengan memperoleh hasil error yang minimum dan jumlah data yang asli tidak jauh berbeda dengan hasil peramalan.Penelitian ini menggunakan metode penentuan panjang interval, yaitu dengan algoritma automatic clustering dengan memilih $\mathrm{p}=5$, selanjutnya hasil peramlan yang diperoleh dihitung nilai errornya menggunakan metode Mean Absolute Percentage Error.

Penelitian sebelumnya tentang perbandingan metode Automatic Clustering-Fuzzy Logical Relationships dengan metode peramalan lain yang dilakukan oleh Robert Kurniawan (2014) "Perbandingan Peramalan Wisatawan di Bali dengan Metode ARIMA dan Automatic Clustering- 
Fuzzy Logical Relationships", Endaryati \& Kurniawan (2015) "Komparasi Metode Peramalan Automatic Clustering Technique and Fuzzy Logical Relationships dengan Single Exponential Smoothing”, dan penerapan metode yang dilakukan Anggodo \& Mahmudy (2016) dalam penelitiannya yang berjudul "Peramalan Butuhan Hidup Minimum Menggunakan Automatic Clustering dan Fuzzy Logical Relationships".

Masing-masing ketiga peneilitian diatas menerapkan dan mebandingkan metode ACFLR dengan metode lain, dan menerapkan metode dalam peramalan permasalahan kehidupan sehari-hari, kedua peneliti Robert Kurniawan dan Endaryati yang membandingkan metode ACFLR dengan metode ARIMA dan Single Exponential Smoothing menyimpulkan bahwa metode ACFLR ini lebih baik dibandingkan dengan metode lain, dibuktikan dengan nilai MSE yang lebih minimum. Sedangkan Anggodo \& Mahmudy (2016) yang melakukan penelitian dengan meramalkan butuhan minimum menggunakan metode ACFLR dan memperoleh nilai error 0,98 dengan memilih $\mathrm{p}=11$, dengan nilai error yang minimum Anggodo menyimpulkan bahwa metode ACFLR dapat digunakan dalam peramalan butuhan hidup minimum dan hasil peramalan yang diperoleh sangat akurat.

\section{KESIMPULAN}

1. Kajian matematis metode Automatic Clustering-Fuzzy Logical Relationships adalah sebagai berikut:
a. Jika hasil fuzzifikasi pada tahun $t$ adalah $A_{j} \rightarrow A_{k}$, maka peramalan pada tahun $t+$ 1 adalah $m_{k}$.
b. Jika hasil fuzzifikasipada tahun $t$ adalah $A_{j}$, dengan $A_{j} \rightarrow$ $A_{k 1}\left(x_{1}\right), A_{k 2}\left(x_{2}\right), \ldots, A_{k p}\left(x_{p}\right)$, maka peramalan pada tahun $t+1$ adalah $\frac{x_{1} \times m k_{1}+x_{2} \times m k_{2}+\cdots+x_{p} \times m k_{p}}{x_{1}+x_{2}+\cdots+x_{p}}$.
c. Jika hasil fuzzifikasi pada tahun $\mathrm{t}$ adalah $A_{j}, A_{j} \rightarrow$ \#, maka peramalan pada tahun $t+1$ adalah $m_{n}$.

2. Hasil peramalan jumlah penduduk di Kota Makassar menggunakan metode Automatic clustering-fuzzy logical relationships dari tahun 2017 ke tahun 2018 dan 2019 mengalami penurunan, dan pada tahun 2019 ke 2020 dan 2021 berturut-turut mengalami peningkatan.

3. Keakuratan hasil peramalan menggunakan metode Automatic clustering-fuzzy logical relationshipsmenunjukkan bahwa hasil peramalan yang diperoleh akurat dengan nilai error dibawah $10 \%$.

Tujuan penelitian ini adalah untuk melakukan peramalan jumlah penduduk di Kota Makassar tahun 2017-2021. Beberapa penelitian yang bisa dilakukan selanjutnya diantaranya adalah dengan melakukan modifikasi pada metode ACFLR. Selain itu, penelitian tentang penerapan metode ACFLR untuk peramalan pada data historis berbeda juga dapat dilakukan. Disamping itu, teknologi dapat pula diterapkan dalam membuat program komputasi dalam bentuk software untuk memudahkan peramalan. 


\section{DAFTAR PUSTAKA}

Abdy, M. (2008). Dasar-Dasar Teori Himpunana Kabur dan Logika Kabur, Makassar: Badan Penerbit UNM.

Badan Pusat Statistik Kota Makassar. (2016). Kota Makassar Dalam Angka 2016. Makassar: BPS Kota Makassar.

Chen SM, Wang NY, \& Pan J R. (2009). Forecasting Enrollments Using Automatic Clustering Techniques and Fuzzy Logic Relationships. An International Journal of Expert Systems With Applications, 33(1). 1-17.

Endaryati, B., \& Kurniawan, R. (2015). Komparasi Metode Automatic clustering Technique and Fuzzy logical relationships dan Single Exponential Smoothing. Media Statistika, 8(2).

Kurniawan, R. (2011). Metode Automatic clustering - Fuzzy Logic Relationships untuk Peramalan Data Univariate. (Tesis, tidak dipublikasikan) Surabaya: Institut Teknologi Sepuluh November.

Kurniawan, R. (2014) . Perbandingan Peramalan Wisatawan di Bali dengan Metode Arima dan Automatic clustering - Fuzzy logical relationships. Jurnal Statistika \& Komputasi Statistik, 1 .

Lee. W.L., Wang. L.H., dan Chen. S.M., (2007), Temperature Prediction and TAIFEX Forecasting Based on Fuzzy Logical Relationships and Genetic Algorithm, Expert Systems with Application, 33. 539-550.

Rahanimi. (2010). Peramalan Jumlah Mahasiswa Pendaftar Pmdk Jurusan Matematika Menggunakan Metode Automatic clustering Dan Relasi Logika Fuzzy (Studi Kasus Di Institut Teknologi Sepuluh Nopember Surabaya). (Skripsi, tidak dipublikasikan). Institut Teknologi Sepuluh November, Surabaya.

Raharja, A., Angraeni, W., \& Aulia, R. V. (2010). Penerapan Metode Exponential Smoothing Untuk Peramalan Penggunaan Waktu Telepon di PT. Telkomsel DIVRE. Jurnal Sistem Informasi, (6).

Robandi, I. (2006). Desain Sistem Tenaga Modern - Optimasi - Logika Fuzzy - Algoritma Genetika. Yogyakarta: Andi Publisher.

Song, Q. dan Chissom, B.S. (1993), Fuzzy time series and its models, Fuzzy Sets and System, 54(3). 269-277 